\title{
Preparation and characterization of hydroquinone based polyoxalate and its application in the removal of heavy metals from water
}

\author{
Diya Alsafadi a, ${ }^{\text {, }}$, Bassam A. Sweileh ${ }^{\mathrm{b}}$ and Fawwaz I. Khalilili \\ ${ }^{a}$ Scientific Research Center, Royal Scientific Society, Amman 11941, Jordan \\ * Corresponding author e-mail: Diya.safadi@rss.jo \\ ${ }^{b}$ Department of Chemistry, The University of Jordan, Amman 11942, Jordan
}

\begin{abstract}
Hydroquinone based polyoxalate was synthesized from oxalyl chloride and hydroquinone. The polymer was characterized with FTIR, ${ }^{1} \mathrm{H}$-NMR, ${ }^{13} \mathrm{C}-\mathrm{NMR}, \mathrm{PXRD}, \mathrm{SEM}$ and thermal analysis. The chelation behaviour of the polymer towards $\mathrm{Pb}(\mathrm{II})$, $\mathrm{Cd}(\mathrm{II})$, and $\mathrm{Hg}(\mathrm{II})$ in aqueous solutions was studied by batch technique as a function of contact time and $\mathrm{pH}$. The polymer showed high metal uptake toward $\mathrm{Pb}(\mathrm{II})$ and $\mathrm{Cd}(\mathrm{II})$ and moderate metal uptake toward $\mathrm{Hg}(\mathrm{II})$. The adsorption capacity was not affected by the $\mathrm{pH}$ of solution. The adsorption data were fitted with second order kinetic model and the isotherms models of Langmuir and Freundlich. Thermodynamics measurements showed that sorption process was spontaneous. Furthermore, the chelating polymer was loaded with metal ions using fixed bed column. For regenerating the loaded polymer, different eluting agents include $\mathrm{HNO}_{3}, \mathrm{H}_{2} \mathrm{SO}_{4}$, and EDTA was investigated. The highest recovery of metal ions was achieved using $\mathrm{HNO}_{3}$, indicating that desorption process was governed by the solubility factor and cation exchange mechanism.
\end{abstract}

\section{Indexing terms/Keywords}

Heavy metals; chelating polymer; adsorption; polyoxalate; isotherm models; desorption.

\section{Academic Discipline And Sub-Disciplines}

Environmental chemistry, Physical chemistry; Adsorption scince and Polymer chemistry

\section{SUBJECT CLASSIFICATION}

Chemistry

\section{TYPE (METHOD/APPROACH)}

Experimental laboratory

\section{Council for Innovative Research}

Peer Review Research Publishing System

Journal: Journal of Advances in Chemistry

\author{
Vol. 10, No. 8 \\ editorjaconline@gmail.com
}




\section{INTRODUCTION}

Excessive release of toxic heavy metals into the environment has posed a great problems worldwide [1]. Unlike organic biodegradable pollutants, heavy metals are stable and cannot be degraded into harmless end products [2]. Furthermore, heavy metals can easily enter the food chain and cause progressive toxic effects with gradual accumulation in living organisms over their lifespan. Lead, mercury and cadmium are examples of such heavy metals that have been classified as priority pollutants by the United States Environmental Protection Agency (USEPA) [3].

Many methods have been evaluated for their ability to remove heavy metals from environment resources particularly, from the waste-water streams. The traditional methods such as chemical precipitation and ultrafiltration did not provide sufficient metals contaminant removal to meet water standards limits [4]. In an alternative approach advance adsorption methods using synthetic chelating polymers [5-8] or clays minerals [9] have been intensively investigated for their high selectivity and efficiency and cost effectiveness.

The backbone of chelating polymers composed active functional groups capable for coordinating with different metal ions. These functional groups usually contain electron donor atoms (Lewis base) such as $\mathrm{N}, \mathrm{O}$ and $\mathrm{S}$ that can coordinate with most of the toxic heavy metals (Lewis acid) [10]. Several criteria are important in the design of chelating polymers include specific and fast metal uptake, high mechanical strength and ability for reusability [11].

Polyoxalates are an interesting class of polymers with two adjacent carbonyl groups in their repeating unit, and these carbonyl groups may act as good ligands for metal complexing. Moreover, polyoxalates have unique properties such as, biodegradability and high mechanical strength [12]. Polyoxalates have been investigated for use in certain applications, include drug delivery [13-14], and water treatment for the removal of heavy metal ions [15]. The synthesis of polyoxalates involve polycondesation of either oxalyl chloride, oxalic acid or oxalic esters with diols. Recently, Polyoxalates have been synthesized from bio-renewable diols via oxalate metathesis polymerization [16].

The chelating behavior of aliphatic polyoxalate (Poly 2,2-dimethyl-1,3-propylene oxalate) toward heavy metals was reported by Abu-Awwad et al [17]. The polymer showed high metal-ion uptake capacity towards $\mathrm{Pb}$ (II) and moderate to low capacity towards $\mathrm{Cd}$ (II) and $\mathrm{Hg}$ (II) ions. In our effort to increase the metal-ion uptake capacity herein, we describe the synthesis and characterization of an aromatic polyoxalate, poly(1,4-phenylene oxalate) (PPO). The sorption properties of PPO toward $\mathrm{Pb}(\mathrm{II}), \mathrm{Cd}(\mathrm{II})$, and $\mathrm{Hg}(\mathrm{II})$ ions was examined and compared with the results obtained from the aliphatic counterpart. A real water sample contaminated with heavy metals was also studied in order to provide evidence for the applicability of the prepared polymer in wastewater treatment.

\section{EXPERIMENTAL}

\subsection{Materials}

Oxalyl chloride, sodium sulfate, potassium carbonate and 4-dimethyl-aminopyridine (4-DMAP) were purchased from Acros. Acetic acid, nitric acid, sulfuric acid, hydrochloric acid and ethylenediamine tetra acetate-disodium salt (EDTA) were supplied from Scharlau. Sodium acetate and sodium perchlorate were purchased from Sigma. Hydroquinone and pyridine were purchased from GPR. For the adsorption studies, $\mathrm{Pb}(\mathrm{II}), \mathrm{Hg}(\mathrm{II})$, and $\mathrm{Cd}(\mathrm{II})$ metal ions were prepared directly from their standard solutions (Standard of $\mathrm{Pb}(\mathrm{II}), \mathrm{Hg}(\mathrm{II})$, and $\mathrm{Cd}(\mathrm{II}), 1000$ ppm, Merck A.G., Germany). Other reagents were purchased as analytical grade.

\subsection{Preparation of Poly(1,4-phenylene oxalate)}

PPO was synthesized using single phase organic solvent polymerization [17] with some modifications. The procedure involved dissolving of hydroquinone $(0.10 \mathrm{~mol})$, pyridine $(0.3 \mathrm{~mol})$ and a catalytic amount of 4 -dimethylaminopyridine (4DMAP) in $100 \mathrm{~mL}$ of chloroform. To this solution $(0.10 \mathrm{~mol})$ oxalyl chloride in $(100 \mathrm{~mL})$ chloroform was added drop wise with stirring.

The reaction mixture was left under stirring for 1 hour at $5{ }^{\circ} \mathrm{C}$, then the ice/water bath was removed and the mixture was left at $25{ }^{\circ} \mathrm{C}$ with stirring for $24 \mathrm{~h}$. After that, $100 \mathrm{~mL}$ of chloroform was added to the mixture and the reaction was quenched with $100 \mathrm{~mL}$ distilled water. The mixture was transferred to a separatory funnel, shacked well and left until an effective separation of the two layers was observed. The organic layer was separated, acidified with aqueous $\mathrm{HCl}$ solution $(8 \% \mathrm{v} / \mathrm{v}, 100 \mathrm{~mL})$ and washed with water and with potassium carbonate solution $(10 \% \mathrm{wt} / \mathrm{v})$ until a neutral washing was obtained. The remaining organic layer was dried over anhydrous sodium sulfate and filtered in $250 \mathrm{~mL}$-round bottomed flask. The solvent was completely evaporated under vacuum at $60^{\circ} \mathrm{C}$. An off-white polymer powder was collected and dried overnight in a vacuum oven at $60{ }^{\circ} \mathrm{C}$. For metal adsorption experiments, the obtained polymer was grained and sieved between 40-60 mesh particle sizes.

\subsection{Polymer characterization}

The infrared spectrum of the PPO polymer was recorded with a Nicolet Impact 400 FTIR-Spectrophotometer (4000-500 $\left.\mathrm{cm}^{-1}\right)$. The ${ }^{1} \mathrm{H}$ - and ${ }^{13} \mathrm{C}-\mathrm{NMR}$ spectra of the polymer were recorded on a Bruker avance DPX 300 Spectrometer. The thermal gravimetric analysis (TGA) of the polymer was studied with NETZCH STA 409 PG/PC Thermal Analyzer. The shape and surface morphology of the polymer was examined with a SUPER SCAN SSX Series (Shimadzu SEM) scanning electron microscope. The crystalinity testing of the polymer was performed with X-ray powdered diffraction (Shimadzu PXRD-6000). The inherent viscosity of the solution of the polyoxalate polymer was measured with a dilution Ubbelohde glass capillary viscometer in a thermostated water bath at $25^{\circ} \mathrm{C}$. 


\subsection{Adsorption kinetics}

The effect of contact time on the rate of metal-ion uptake was studied using batch equilibrium technique by the following manner. A $100 \mathrm{mg} \pm 0.1 \mathrm{mg}$ of the dried polymer was suspended in $25 \mathrm{~mL}$ of acetate-acetic acid buffer $\mathrm{pH} 5.0$ for two $\mathrm{h}$. To this mixture, $25.0 \mathrm{~mL}$ of metal ions solution (300 ppm $\mathrm{Pb}(\mathrm{II}), \mathrm{Hg}(\mathrm{II})$, and $\mathrm{Cd}(\mathrm{II})$ ) were added. After being shaken for a definite period of time at $25{ }^{\circ} \mathrm{C}$, the mixture was filtered and the amount of metal ion remaining in the filtrate was determined with optical emission inductively coupled plasma spectrometer (Shimadzu ICPS-7510). The adsorption capacity (q) of metal ions was calculated as follows:

$$
q=\left(C_{0}-C_{e q}\right) V / m
$$

Where $\mathrm{V}$ is the volume of aqueous solution, $\mathrm{C}_{0}$ and $\mathrm{C}_{\mathrm{eq}}$ are the concentrations of initial and residual metal ions, respectively and $m$ is the mass of the polymer.

In order to examine the controlling mechanism of adsorption process such as mass transfer and chemical reaction, the kinetic data were modeled using first and second order kinetic models. The first-order kinetic equation and second order kinetic equation are expressed as Eq. (2) and Eq. (3), respectively.

$$
\begin{aligned}
& \log \left(q_{e}-q_{t}\right)=\log q_{e}-K_{1} t / 2.303 \\
& t / q_{t}=1 / K_{2} q_{e}^{2}+t / q_{e}
\end{aligned}
$$

Where $\mathrm{q}_{\mathrm{e}}$ is the amount of metal ion adsorbed at equilibrium (mg metal $/ \mathrm{g}$ polymer); $\mathrm{q}_{\mathrm{t}}$ is the amount of metal adsorbed ( $\mathrm{mg}$ metal ion/g polymer) at time $\mathrm{t}$; $\mathrm{t}$ is the time in hours (h); $\mathrm{K}_{1}$ and $\mathrm{K}_{2}$ are the rate constants of first and second order kinetic equations (g polymer/ mg metal.h), respectively.

The general expression for the distribution coefficient Kd was calculated using the following equation:

$\mathrm{K}_{\mathrm{d}}=\frac{\text { Metal ion adsorbed on the polymer }(\mathrm{mg})}{\text { Metal ion remain in the solution }(\mathrm{mg})} \times \frac{\text { Volume of solution }(\mathrm{ml})}{\text { Weight of polymer }(\mathrm{g})}$

For evaluating the effect of $\mathrm{pH}$ on the adsorption process similar experiments were performed using different buffer solutions of $\mathrm{pH} 4.0,5.0$ and 6.0 at fixed contact time of $24 \mathrm{~h}$.

\subsection{Adsorption isotherms studies}

Adsorption isotherms for $\mathrm{Pb}(\mathrm{II}), \mathrm{Cd}(\mathrm{II})$, and $\mathrm{Hg}(\mathrm{II})$ ions were carried out by taking a mass of $100 \mathrm{mg} \pm 0.1 \mathrm{mg}$ of the polymer, swelled latter with $25 \mathrm{~mL}$ of sodium acetate-acetic acid buffer, pH 5.0 for two h. $25.0 \mathrm{~mL}$ of metal solutions with concentration ranging from (10-150) ppm for each metal were added. The mixtures were shaken for $24 \mathrm{~h}$ at different temperatures $\left(25^{\circ} \mathrm{C}, 35^{\circ} \mathrm{C}\right.$ and $\left.45^{\circ} \mathrm{C}\right)$. The adsorption isotherms were also studied using similar conditions but under different $\mathrm{pH}$ values of 4 and 6.

The adsorption behavior of metal ions onto polymer surface was described using the linearized Langmuir isotherm Eq. (5) and Freundlich isotherm Eq. (6) plots [19].

$$
\begin{gathered}
1 / q=\left(1 /\left(q_{m} K_{L}\right)\right) 1 / c+1 / q_{m} \\
\log q=\log K_{F}+1 / n \log c
\end{gathered}
$$

Where $\mathrm{c}$ is the equilibrium concentration of the metal ion in solution ( $\mathrm{mg} / \mathrm{L})$, $\mathrm{q}$ the equilibrium adsorption capacity (mg/g), $\mathrm{qm}$ the monolayer saturated adsorption capacity $(\mathrm{mg} / \mathrm{g})$ and $\mathrm{K}_{\mathrm{L}}, \mathrm{K}_{\mathrm{F}}, \mathrm{n}$ are the constants.

In order to understand the possible adsorption mechanism involved in the removal process, thermodynamic functions for the system, including changes in Gibbs free energy $\left(\Delta \mathrm{G}^{*}\right)$, changes in enthalpy of adsorption $\left(\Delta \mathrm{H}^{*}\right)$ and changes in entropy of adsorption $\left(\Delta S^{*}\right)$, were calculated using Eq. (7) and Eq. (8) [20]. 
Where $\mathrm{K}_{d}$ is the equilibrium constant, $\mathrm{R}$ is the universal gas constant and $\mathrm{T}$ is the temperature in Kelvin.

The change in Gibbs free energy $\left(\Delta G^{*}\right)$ was calculated using the following equation:

$$
\Delta G^{*}=\Delta H^{*}-T \Delta S^{*}
$$

\subsection{Metal ion-uptake by the polymer using fixed bed column}

Glass column with $150 \mathrm{~mm}$ length and $10 \mathrm{~mm}$ inner diameter was used in this experiment. The column was packed with $0.5 \mathrm{~g} \pm 0.0001 \mathrm{~g}$ of dried polymer. $50 \mathrm{~mL}$ acetate-buffer, $\mathrm{pH} 5.0$ was added and the polymer allowed swelling for $24 \mathrm{~h}$. The acetate buffer was then followed at a flow rate of $1.0 \mathrm{~mL} / \mathrm{min}$. A sample $50.0 \mathrm{~mL}$ containing $1000 \mathrm{ppm} \mathrm{Pb}(\mathrm{II})$, was then passed through the column at the same flow rate $(1.0 \mathrm{~mL} / \mathrm{min})$. The eluate was collected in a $50 \mathrm{~mL}$ volumetric flask, and the concentration of the metal ion was determined by ICPS. The same experimental conditions were used for the determination of $\mathrm{Cd}(\mathrm{II})$ and $\mathrm{Hg}$ (II) ions uptake, where the sample which passed through the column was 1000 ppm for both $\mathrm{Cd}(\mathrm{II})$ and $\mathrm{Hg}(\mathrm{II})$.

\subsection{Desorption Studies}

In order to determine the reusability of the polymer, consecutive adsorption-desorption steps were performed. The desorption of the $\mathrm{Pb}(\mathrm{II}), \mathrm{Cd}(\mathrm{II})$, and $\mathrm{Hg}(\mathrm{II})$ ions, were carried under column condition, where the polymer was loaded with each metal ion as described in previous section. 50 mLof three eluting agents, $1 \mathrm{~N} \mathrm{HNO}_{3}, 1 \mathrm{~N} \mathrm{H}_{2} \mathrm{SO}_{4}$, and $0.5 \mathrm{~N}$ EDTA were used for polymer recovery from adsorbed metal ion, keeping the flow rate for elution at $1 \mathrm{~mL} / \mathrm{min}$. The metal ion in the eluate was collected and the concentration was determined with ICP. The percentage recovery of each metal ion was calculated with Eq. (9).

$$
\% \text { Recovery }=\frac{\text { Amount of metal ions in the elution agent }}{\text { Amount of metal ions adsorbed on the polymer }}
$$

\section{RESULTS AND DISCUSSION}

\subsection{Polymer synthesis}

The synthesis of PPO was performed by polycondensation of oxalyl chloride and hydroquinone, the reaction was catalyzed with pyridine as given in Scheme 1.

An off-white powder with $85 \%$ yield was obtained. The synthesized polymer was insoluble in most common organic solvents such as chloroform, dimethyl formamide (DMF), tetrahydrofuran (THF) 1,4-dioxane and showed good solubility only in dimethyl sulfoxide (DMSO).

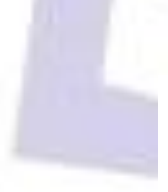<smiles>Oc1ccc(O)cc1</smiles><smiles>O=C(Cl)C(=O)Cl</smiles><smiles>CCCCCCC(=O)C(=O)Oc1ccc(OC)cc1</smiles>

Scheme 1. Preparation of PPO.

\subsection{Polymer characterization}

\subsubsection{FTIR spectrum of the polymer}

PPO was analyzed with FTIR spectroscopy (Figure 1). The FTIR spectrum of the polymer exhibits characteristic absorption bands for the major bonds involved in the polymer. The results of the IR analysis ( $\mathrm{NaCl}$ disc) showed two strong absorption bands due to the stretching vibration of the carbonyl group $(C=O)$ of the oxalate function at $1708 \mathrm{~cm}^{-1}$ and at $1757 \mathrm{~cm}^{-1}$, and due to the (C-O-C) at 1137,1179 and $1229 \mathrm{~cm}^{-1}$. The IR spectrum also showed broad band at about $3252 \mathrm{~cm}^{-1}$, this band was assigned to the terminal aromatic hydroxyl groups of the oligomers that formed. 


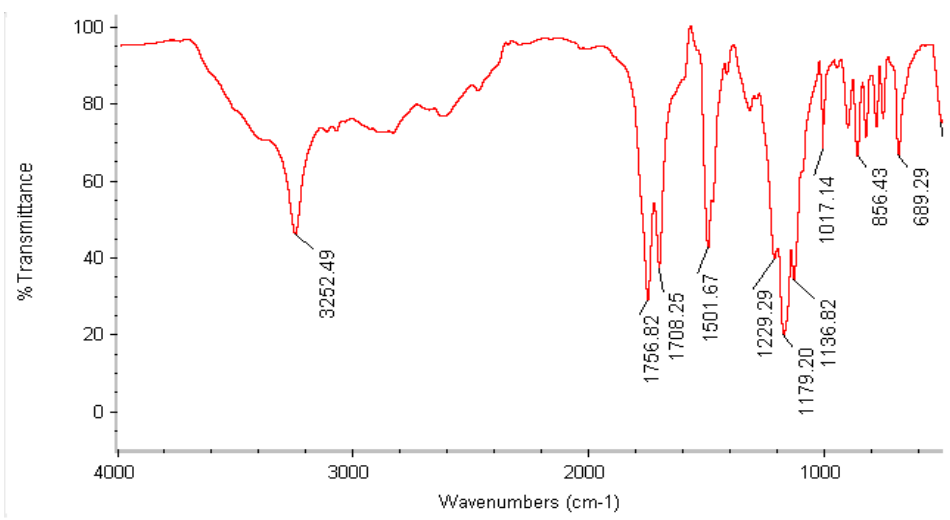

Figure 1. IR spectrum of PPO.

\subsubsection{NMR spectra}

PPO structure was also confirmed with NMR spectroscopy. The protons of the aromatic ring of hydroquinone unit were observed as singlet at $\delta=7.4 \mathrm{ppm}$. In addition to this peak, two other small aromatic peaks were also observed in the ${ }^{1} \mathrm{H}$ NMR spectrum; the first was observed at $\delta=7.1 \mathrm{ppm}$ which was attributed to the ring protons in ortho position to a terminal hydroxyl group of phenol. The second peak was observed at $\delta=6.8$ which was attributed to the ring protons in meta position to a terminal hydroxyl group of phenol. The proton of a phenolic hydroxyl group was observed at $\delta=3.4$ $\mathrm{ppm}$. The appearance of these small signals in the ${ }^{1} \mathrm{H}$-NMR spectrum of PPO indicates that the terminal phenolic units of the end group are detectable. The small sizes of these signals indicate that the product obtained is the oligomer rather than the mature polymer. The ${ }^{1} \mathrm{H}-\mathrm{NMR}$ spectrum is shown in Figure 2.
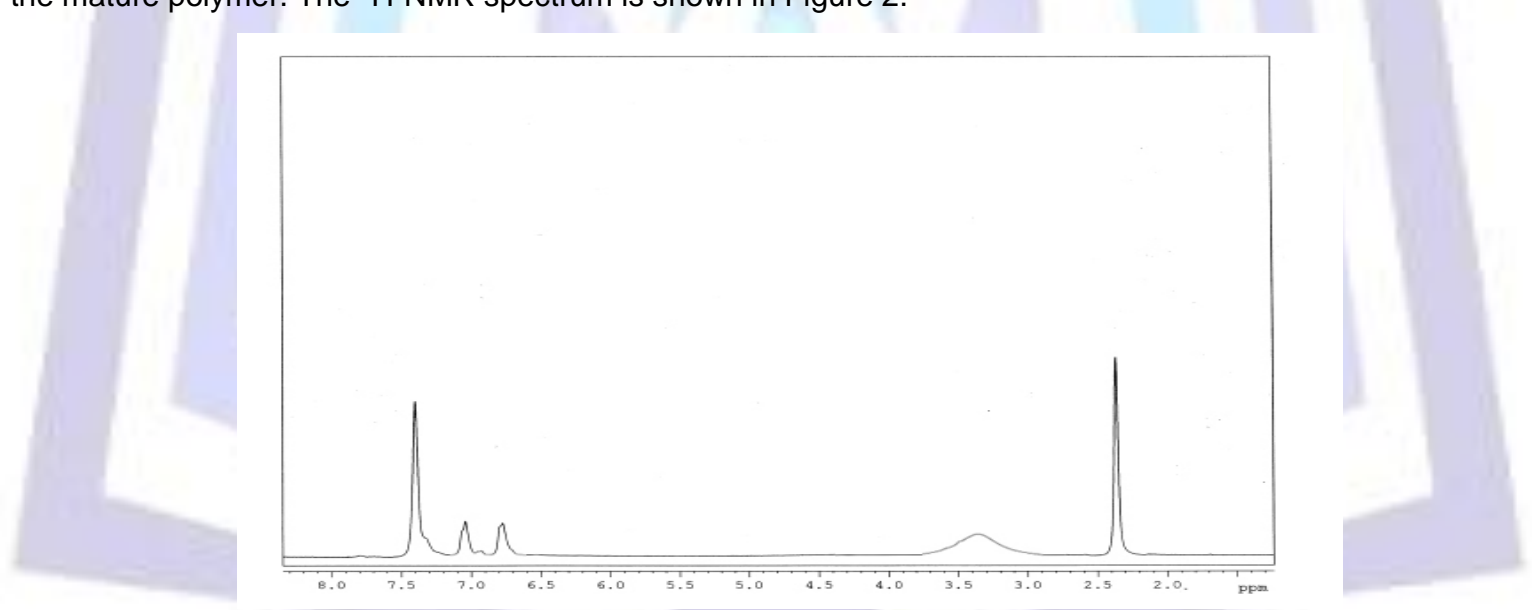

Figure 2. ${ }^{1} \mathrm{H}-\mathrm{NMR}$ spectrum of PPO

The ${ }^{13} \mathrm{C}-\mathrm{NMR}$ spectrum of the polymer is presented in Figure 3. The signal of the carbonyl carbon atoms of the oxalate unit appeared at $156.2 \mathrm{ppm}$. The carbon atoms of the aromatic ring of hydroquinone unit were observed at $122.5 \mathrm{ppm}$ and $148.5 \mathrm{ppm}$. The signal that appeared at $122.5 \mathrm{ppm}$ was attributed to aromatic methine carbon atoms, and the aromatic quaternary carbon that is directly bonded to oxygen observed at $148.5 \mathrm{ppm}$. In addition to these peaks, other signals were also observed at $116.2,123.2,142.7$, and $155.7 \mathrm{ppm}$ which were attributed to the terminal phenolic end . 


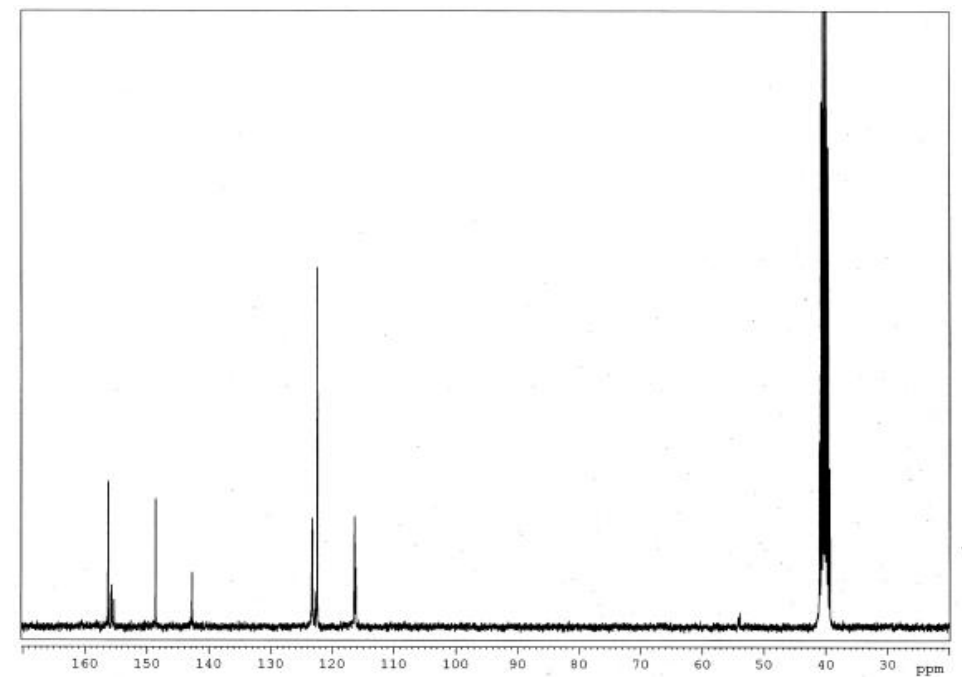

Figure $3 .{ }^{13} \mathrm{C}-\mathrm{NMR}$ spectrum of PPO.

\subsubsection{Thermal analysis}

To examine the thermal degradation behavior of the polymer, thermogravimetric analysis (TGA) was conducted under dry nitrogen atmosphere. The TGA curve of the polymer displayed almost one stage characteristics with a slow loss of mass starting from $77^{\circ} \mathrm{C}$ to $168{ }^{\circ} \mathrm{C}$ and a relatively fast loss between $193^{\circ} \mathrm{C}$ to about $380{ }^{\circ} \mathrm{C}$ (Figure 4). A similar thermal decomposition analysis of polyoxalate has been previously reported by Thibeault et al [21]. The TGA data of polyoxalates were explained by the decarboxylation of the oxalate groups, and the formation of polyenes and $\mathrm{CO}_{2}$.
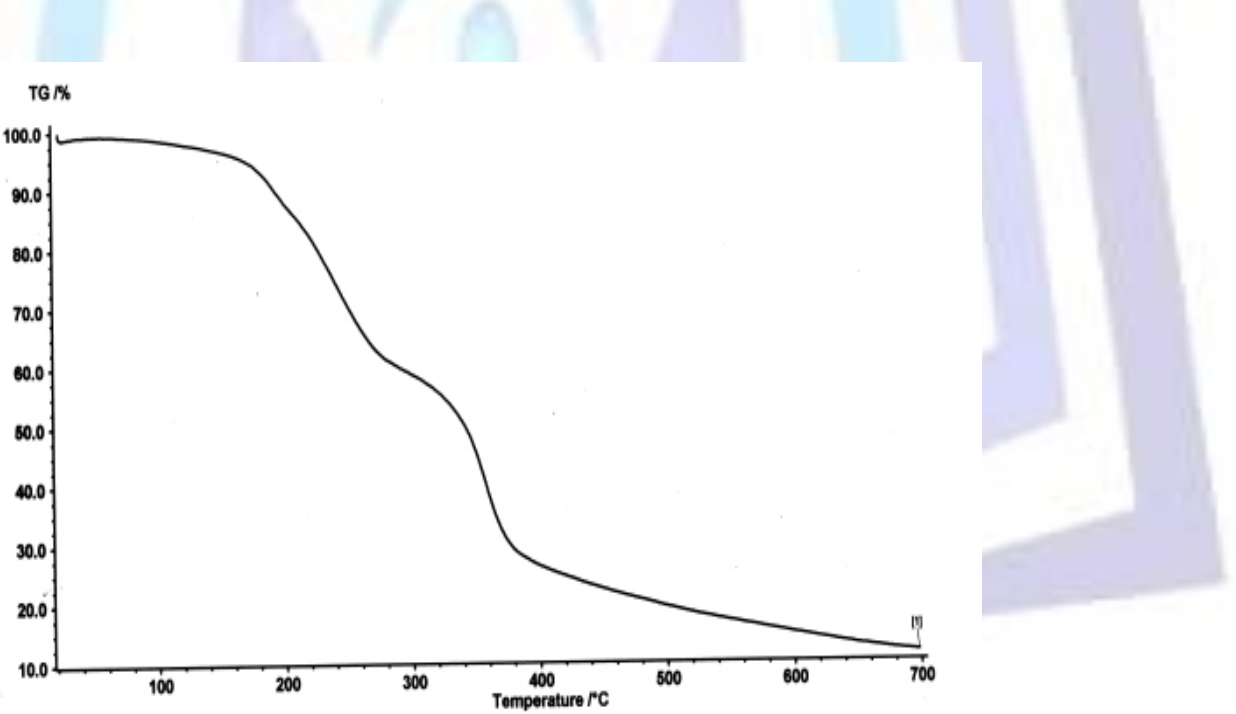

Figure 4. TGA curve for PPO.

\subsubsection{Scanning electron microscopy and $X$-ray diffraction analysis}

The surface feature of PPO was examined through scanning electron microscopy (SEM) (Figure 5). It is clearly seen that there are abundant pores distributed on the polymer surface. The existence of these pores would provide convenient diffusion channels for metal ions into the polymer core. These pores would play an important role when the polymer used for metal uptake from aqueous solution. 

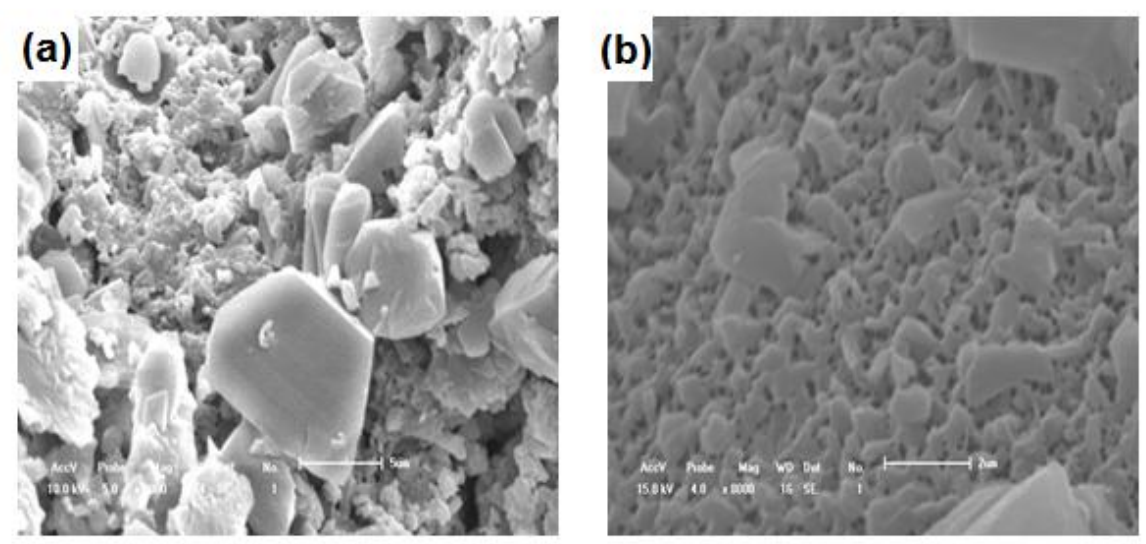

Figure 5. SEM images of PPO (a) magnification = 3000 time and (b) magnification $=8000$ time.

The powder X-ray diffraction (PXRD) pattern of the synthesized polymer is depicted in Figure 6 . The diffraction pattern showed that the PPO is found to be more amorphous in nature; this implies that the polymer structure has a relatively low regular packed crystal system within its molecules. The amorphous structure could be arisen from the existence of aromatic bulky group which enhance the irregularity between the polymer molecules.

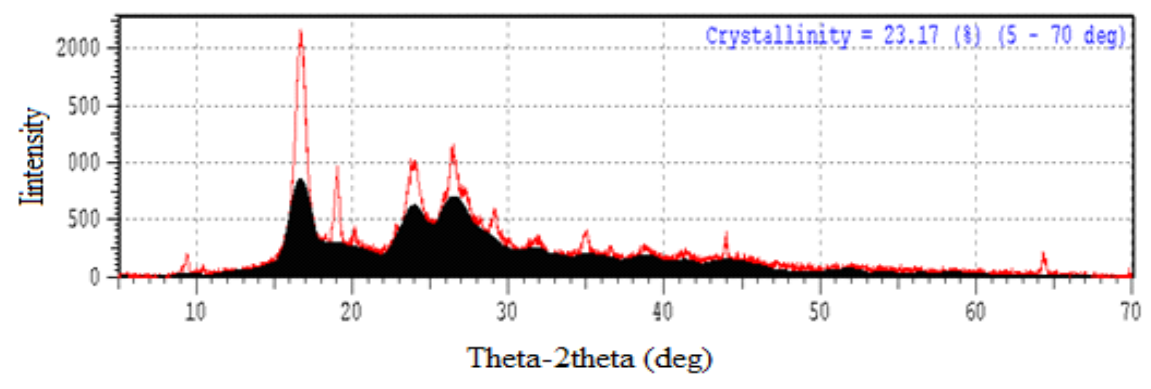

Figure 6. PXRD pattern of PPO. The percent of crystallinity (red) equal $23 \%$ and the percent amorphous (black) equal $77 \%$.

\subsubsection{Viscosity measurements}

The inherent viscosity of the polymer was determined from the viscosity measurements of diluted polymer solutions ( 0.5 $\mathrm{g} / \mathrm{dl}$ ) in dimethyl sulfoxide (DMSO), at $25{ }^{\circ} \mathrm{C}$ using Ubbelhode glass capillary viscometer. The polymer had inherent viscosity of $0.14 \mathrm{dl} / \mathrm{g}$. From this value, the polymer prepared had a low to moderate inherent viscosity, which means that the polymer with a low to moderate molecular mass was produced.

\subsection{Adsorption properties}

\subsubsection{Effect of $\mathrm{pH}$}

The effect of $\mathrm{pH}$ on the uptake of $\mathrm{Pb}(\mathrm{II}), \mathrm{Cd}(\mathrm{II})$ and $\mathrm{Hg}(\mathrm{II})$ by $\mathrm{PPO}$ was studied using batch procedure at $\mathrm{pH}$ range (4 -6) for a fixed contact time of $24 \mathrm{~h}$ at $25{ }^{\circ} \mathrm{C}$ (Figure 7). The results in Figure 7 show that the changing of pH has no effect on the sorption capacity profile of the polymer. This could be related to the fact that the polymer has no ionizable functional groups. Figure 7 also indicates that the selectivity of $\mathrm{PPO}$ is high toward $\mathrm{Pb}(\mathrm{II})$ and $\mathrm{Cd}(\mathrm{II})$ and moderate uptake towards $\mathrm{Hg}$ (II). 


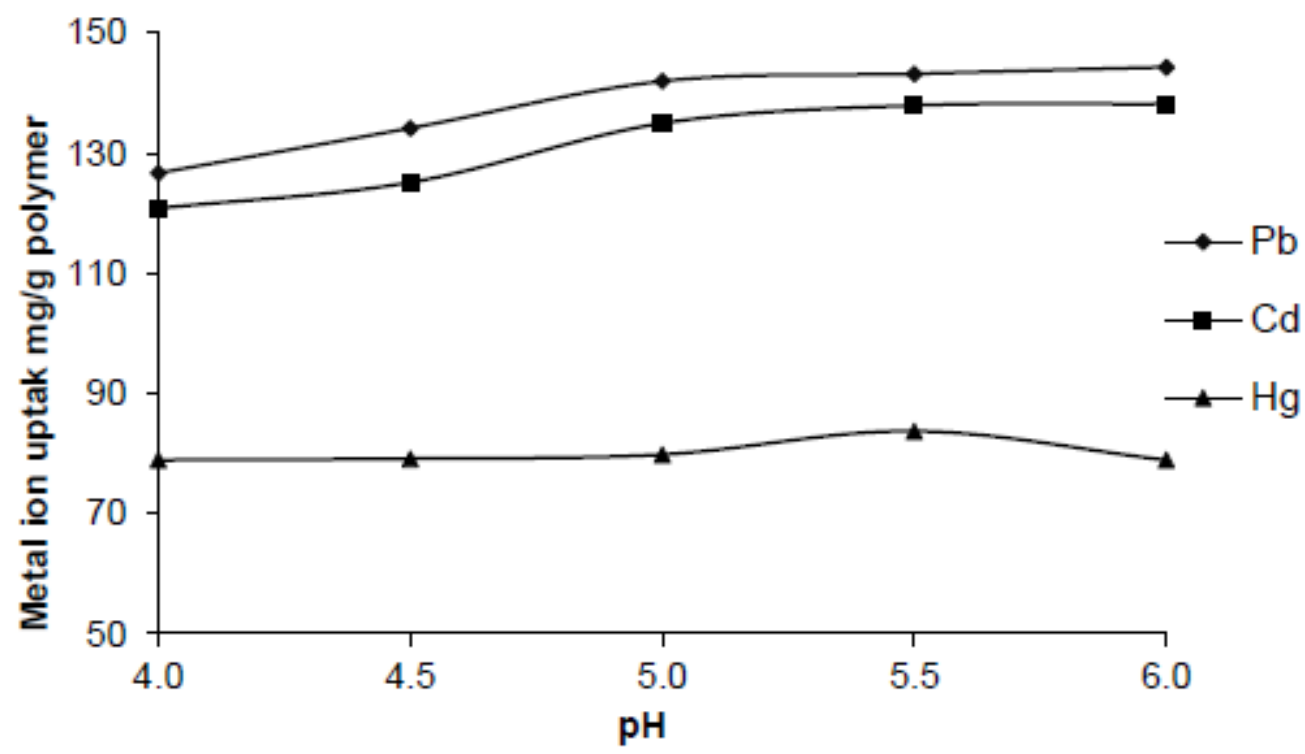

Figure 7. Metal uptake at different pHs.

To confirm this selectivity, the distribution coefficient of metal ions $\left(\mathrm{K}_{\mathrm{d}}\right)$ between the polymer phase and the aqueous phase was calculated at $\mathrm{pH}$ ranging from $4-6$ (Figure 8). As expected the distribution ratio of the metal ions follows the order $\mathrm{Pb}(\mathrm{II})>\mathrm{Cd}(\mathrm{II})>\mathrm{Hg}(\mathrm{II})$. Interestingly, Figure 8 shows that there is no linear correlation between the $\mathrm{pH}$ values and the logarithm of distribution coefficients (Log Kd) which implies that the adsorption process is beyond the ion exchange behaviour or to the lack of acidic/basic functional groups [22]

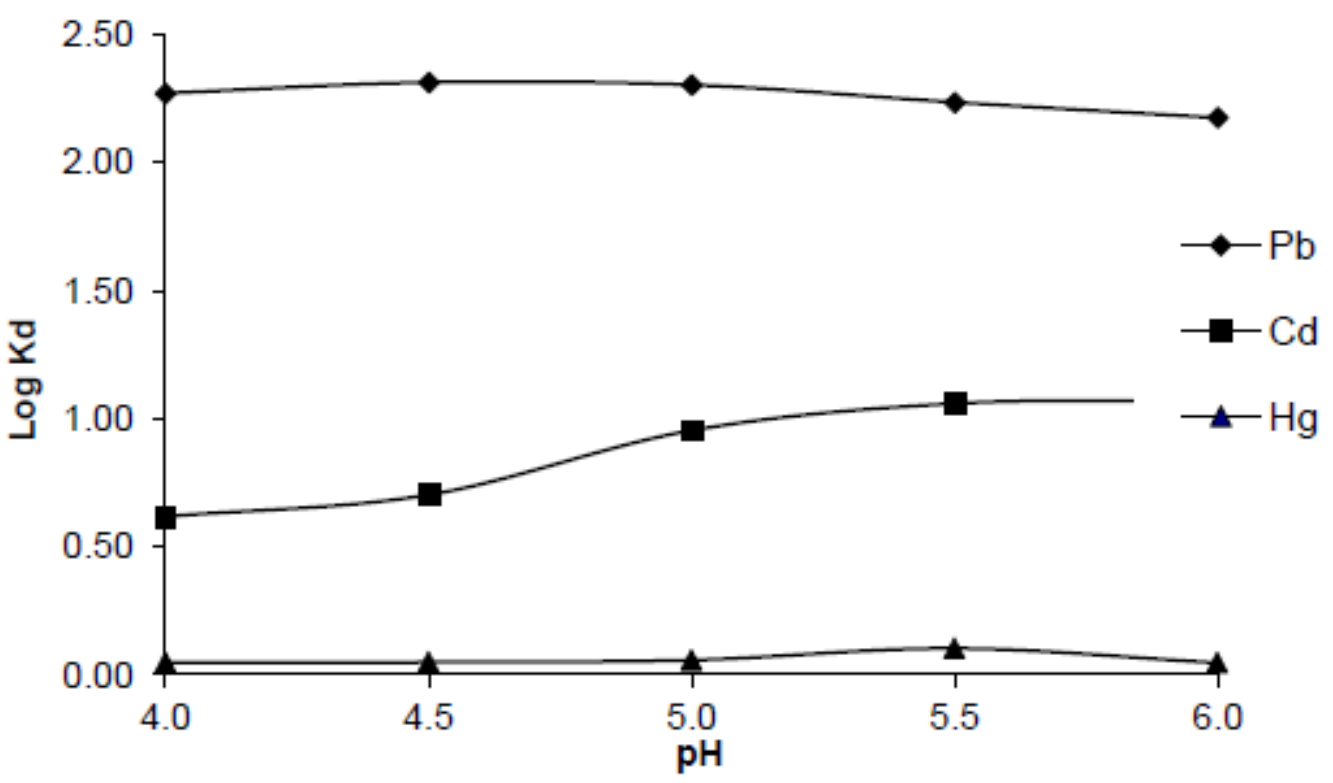

Figure 8. Relation between Log $\mathrm{K}_{\mathrm{d}}$ versus pHs.

\subsubsection{Adsorption kinetics}

The rate of metal ion uptake by the PPO was evaluated at different time intervals and the results are presented in Figure 9. The time profile of metal ions adsorption showed high sorption rate during the first 15 minutes with percent uptake for $\mathrm{Pb}(\mathrm{II}), \mathrm{Cd}(\mathrm{II})$ and $\mathrm{Hg}(\mathrm{II}) 98.33 \%, 88.97 \%$ and $48.12 \%$, respectively. Furthermore, the uptake for all metal ions increase with time until complete saturation (plateau) was obtained after 12 hours of contact time. The fast metal ion uptake could 
be attributed to the porous structure of the polymer which accelerates the metal ion diffusion toward polymer active groups.

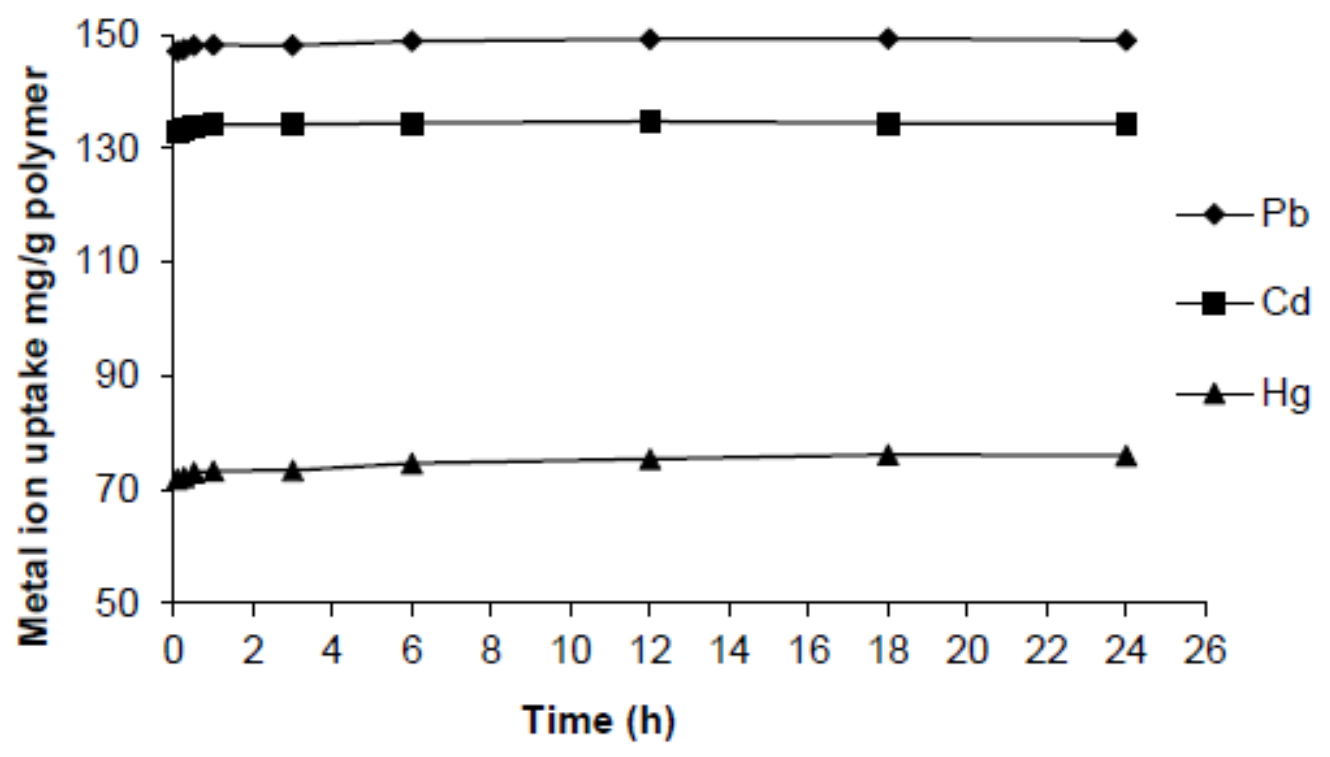

Figure 9. Metal uptake as a function of contact time, at pH 5 and initial concentration of 300 ppm.

The first and second order models (Eq. (2) and Eq. (3)) were used to fit the experimental data of adsorption kinetics. For the first order model the amount of metal ion adsorbed at equilibrium $\left(q_{e}\right)$ and the rate constant $\left(K_{1}\right)$ were calculated from the slope and intercept for the plots of $t$ vs. $\log \left(q_{e}-q_{t}\right) \quad$ (Figure10). For the second order model, the values of qe and $K_{2}$ at different concentrations were calculated from the slope and intercept of the plots of $t \mathrm{vs} . t / q_{t}$ (Figure 11). The obtained values are presented in Table 1.

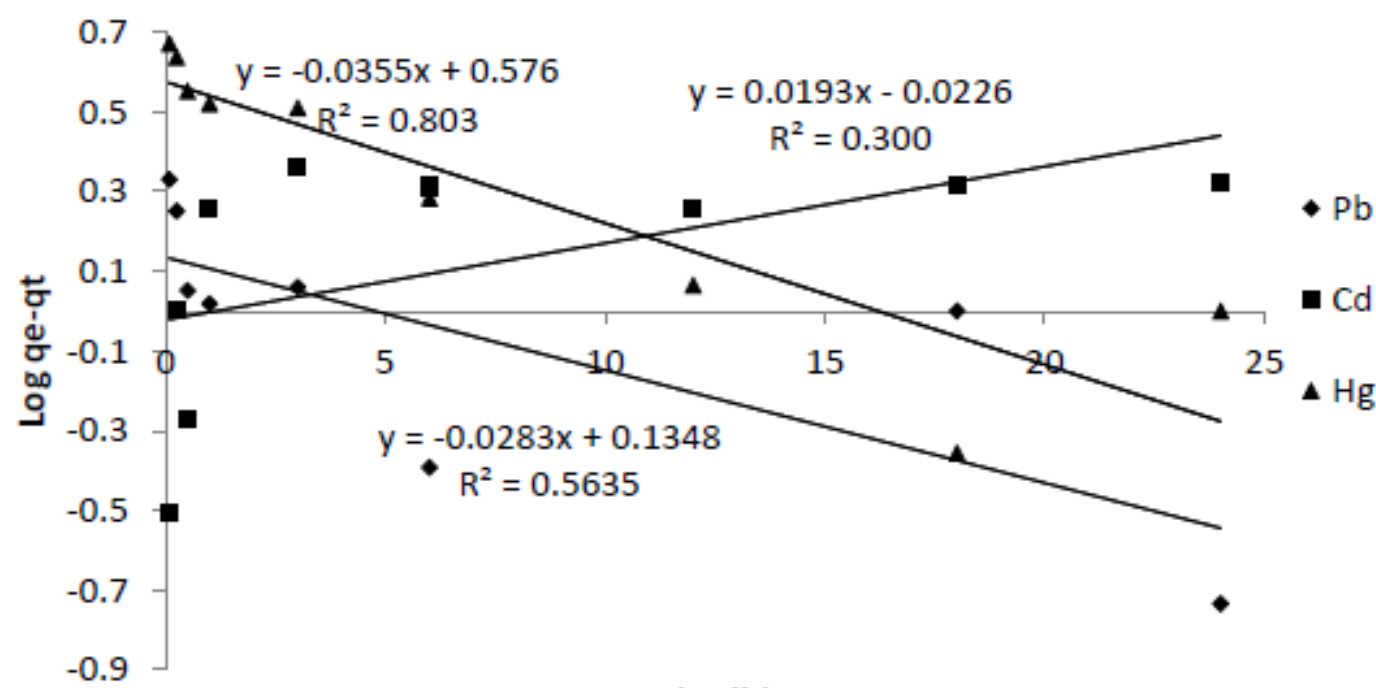

$\operatorname{Tim}(\mathbf{h})$

Figure 10. Plot of first-order kinetic model. 


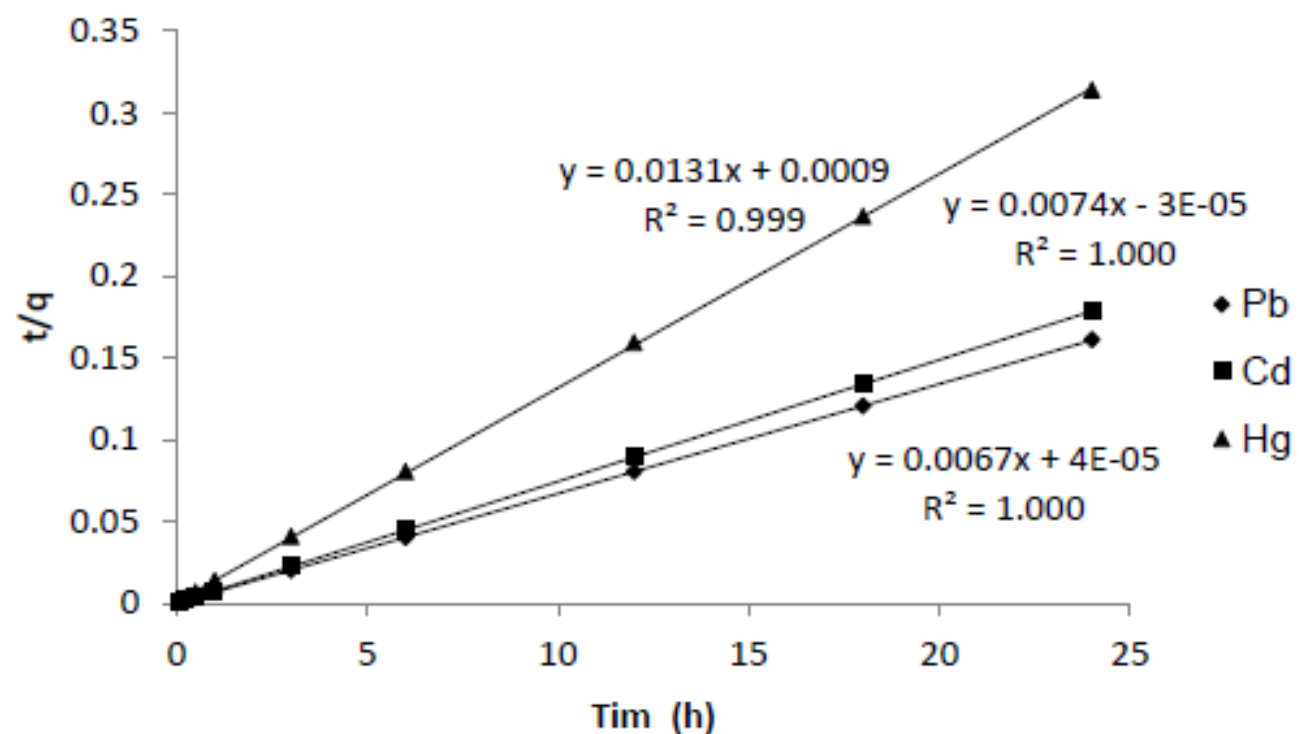

Figure 11. Plot of second-order kinetic model.

Table 1 First order and second order adsorption rate parameters

\begin{tabular}{|lc|c|c|c|crc|}
\hline Metal & \multicolumn{3}{c}{ First order kinetic model } & \multicolumn{3}{c|}{ Second order kinetic model } \\
\hline & $\mathrm{q}_{\mathrm{e}}(\mathrm{exp}) \mathrm{mg} \mathrm{g}^{-1}$ & $\mathrm{q}_{\mathrm{e}}$ (cal) $\mathrm{mg} \mathrm{g}^{-1}$ & $\mathrm{~K}_{1} \mathrm{~h}^{-1}$ & $\mathrm{R}_{1}$ & $\mathrm{q}_{\mathrm{e}}$ (cal) $\mathrm{mg} \mathrm{g}^{-1}$ & $\mathrm{~K}_{2} \mathrm{~g} \mathrm{mg}^{-1} \mathrm{~h}^{-1}$ & $\mathrm{R}_{2}$ \\
\hline $\mathrm{Pb}(\mathrm{II})$ & 149.30 & 1.36 & 0.04 & 0.564 & 149.25 & 1.12 & 0.999 \\
\hline $\mathrm{Cd}(\mathrm{II})$ & 133.33 & 1.05 & 0.05 & 0.300 & 135.13 & 1.83 & 1.000 \\
\hline $\mathrm{Hg}(\mathrm{II})$ & 57.80 & 3.77 & 0.08 & 0.804 & 76.33 & 0.19 & 1.000 \\
\hline
\end{tabular}

From the values of correlation coefficients $R_{1}$ and $R_{2}$ in Table 1 , we can predict that the adsorption kinetics followed a second order kinetic model for all the selected metals, while the first-order kinetic model fits poorly the experimental data. Furthermore, the experimental $q_{e}$ values were very close to the calculated qe from second order kinetic. These results indicate that the rate-limiting step of the adsorption process is the chemical adsorption [23].

\section{Adsorption isotherms .3.3.3}

The adsorption isotherms were determined for $\mathrm{Pb}) \mathrm{II}$ ), $\mathrm{Cd}(\mathrm{II})$, and $\mathrm{Hg}(\mathrm{II})$ in the range of concentrations from $10-150 \mathrm{mg} / \mathrm{L}$ at $\mathrm{pH} 5.0$ and different temperatures $\left(25^{\circ} \mathrm{C}, 35^{\circ} \mathrm{C}\right.$ and $\left.45^{\circ} \mathrm{C}\right)$. The results of the adsorption isotherm were analyzed using the linearized adsorption isotherm of Langmuir and Freundlich. The isotherm data for the investigated heavy metal ions are summarized in Table 2. 
Table 2. Langmuir and Freundlich isotherm parameters for $\mathrm{Pb}(\mathrm{II}), \mathrm{Cd}(\mathrm{II})$, and $\mathrm{Hg}$ (II) with PPO.

\begin{tabular}{|c|c|c|c|c|c|c|c|}
\hline \multirow[t]{2}{*}{$\mathrm{T}\left({ }^{\circ} \mathrm{C}\right)$} & \multirow[t]{2}{*}{ Metal ion } & \multicolumn{3}{|c|}{ Langmuir equation parameters } & \multicolumn{3}{|c|}{ Freundlich equation parameters } \\
\hline & & $\mathrm{q}_{\mathrm{m}}(\mathrm{mg} / \mathrm{g})$ & $\mathrm{K}_{\mathrm{L}}(\mathrm{L} / \mathrm{g})$ & $\mathrm{R}_{1}$ & $\mathrm{~K}_{\mathrm{F}}$ & $\mathrm{n}$ & $\mathrm{R}_{2}$ \\
\hline \multirow{3}{*}{25} & $\mathrm{~Pb}(\mathrm{II})$ & * & * & 0.932 & 2.40 & 0.60 & 0.970 \\
\hline & $\mathrm{Cd}(\mathrm{II})$ & 133.33 & $5.74^{*} 10^{-3}$ & 0.998 & 0.76 & 1.03 & 0.994 \\
\hline & $\mathrm{Hg}(\mathrm{II})$ & 57.80 & 0.03 & 0.992 & 2.89 & 1.62 & 0.928 \\
\hline \multirow{3}{*}{35} & $\mathrm{~Pb}(\mathrm{II})$ & * & * & 0.990 & 3.67 & 0.71 & 0.990 \\
\hline & $\mathrm{Cd}(\mathrm{II})$ & 128.21 & $7.87^{*} 10^{-3}$ & 0.964 & 1.03 & 1.11 & 0.988 \\
\hline & $\mathrm{Hg}(\mathrm{II})$ & 28.33 & 0.089 & 0.972 & 2.39 & 1.61 & 0.995 \\
\hline \multirow{3}{*}{45} & $\mathrm{~Pb}(\mathrm{II})$ & * & * & 0.990 & 0.18 & 0.50 & 0.969 \\
\hline & $\mathrm{Cd}(\mathrm{II})$ & 123.46 & $3.86^{*} 10^{-3}$ & 0.957 & 0.88 & 1.14 & 0.954 \\
\hline & $\mathrm{Hg}(\mathrm{II})$ & 31.35 & 0.056 & 0.950 & 1.91 & 1.42 & 0.929 \\
\hline
\end{tabular}

According to Table 2 the equilibrium adsorption $\left(q_{m}\right)$ of the polymer towards metal ions fall in the order: $\mathrm{Pb}(\mathrm{II})>\mathrm{Cd}(\mathrm{II})>$ $\mathrm{Hg}(\mathrm{II})$. This sequence could be attributed to the stability of complexes that formed between the donor atom (oxygen) in polymer active groups and the type of metal ions. The stability of metal complexes can be explained by the hard and soft acids and bases (HSAB) theory, in which hard acids tend to associate with hard bases, and soft acids with soft bases [24]. Based on HSAB theory, $\mathrm{Pb}(\mathrm{II})$ and $\mathrm{Cd}$ (II) (relatively hard acids) have high tendency to make strong complexes with hard donor atom like oxygen. On the other hand, $\mathrm{Hg}(\mathrm{II})$ is a very soft metal and its coordination chemistry favour the liner arrangement with ligands and this could decrease the possibility of forming stable chelate ring with polymer active sites.

The correlation coefficient $\left(R^{2}\right)$ is a mathematical expression which reveals the favorability of the adsorption process. Since $R^{2}$ values (Langmuir) listed in Table 2 are very close to 1, the adsorption of all metal ions onto PPO followed well the Langmuir isotherm equation. The high fitness of Langmuir isotherm gives indication for homogeneous monolayer coverage of PPO active sites by the metal ions.

A comparative study for PPO with previously reported resins was established, the data was expressed in terms of adsorption capacity as shown in Table 3. 
Table 3. Adsorption capacities for $\mathrm{Pb}(\mathrm{II}), \mathrm{Cd}(\mathrm{II})$, and $\mathrm{Hg}(\mathrm{II})$ onto $\mathrm{PPO}$ and various adsorbents reported in the previous literatures.

\begin{tabular}{|l|c|c|c|}
\hline \multirow{2}{*}{ Chelating Polymer } & \multicolumn{3}{c|}{ (Adsorption capacity (mg/g) } \\
\cline { 2 - 4 } & $\mathrm{Pb}(\mathrm{II})$ & $\mathrm{Cd}(\mathrm{II})$ & $\mathrm{Hg}(\mathrm{II})$ \\
\hline Cross-linked magnetic chitosan-phenylthiourea [25] & - & 120.3 & 134.4 \\
\hline Bis[2-(2 benzothiazolylthioethyl)sulphoxide] [26] & 76.7 & 40.3 & 270.8 \\
\hline Silica-supported dithiocarbamate [27] & 82.9 & 40.5 & 80.2 \\
\hline Polysiloxane resins modified by bisglycidyl calix[4]arene [28] & 62.1 & - & 80.0 \\
\hline \multicolumn{1}{|c|}{ [Polyamine chelating resins with sulfide group [29 } & 207.0 & 56.2 & 421.3 \\
\hline $\begin{array}{l}\text { Polystyrene chelating resin with imidazolylazo benzene } \\
\text { functional group having azo group [30] }\end{array}$ & 51.8 & 15.7 & 22.1 \\
\hline Polystyrene supported dithiocarbamates [31] & 4.1 & 2.3 & 6.0 \\
\hline Poly(2,2-dimethyl-1,3-propylene oxalate) [17] & - & 38.6 & 44.8 \\
\hline PHQ & - & 133.3 & 57.8 \\
\hline
\end{tabular}

The results presented in Table 3 reveals that, PPO has a good advantage in adsorption of Cd(II) more than the previously reported resins. Compared with aliphatic polyoxalate [16] in Table 3, the adsorption capacities of PPO for Cd(II) and Hg(II) are higher. The high potential of PPO for uptake of heavy metals can be explained by the presence of phenyl group in the polymer structure which enhance the chelating interaction between the the donor atom (oxygen) and metal ions. A similar effect of the aromatic group has been previously reported in aromatic polyamides [32]. The authors reported that the presence of an aromatic group in the chelating polymer structure improves the chemical stability and binding ability of the polymer to metal ions.

\subsubsection{Thermodynamics of Adsorption on polymer}

For further exploration the adsorption mechanism of heavy metals onto PPO, the thermodynamic functions for the system, including changes in Gibbs free energy $\left(\Delta \mathrm{G}^{*}\right)$, change in enthalpy of adsorption $\left(\Delta \mathrm{H}^{*}\right)$ and changes in entropy $\left(\Delta \mathrm{S}^{*}\right)$ were calculated. The values of enthalpy $\left(\Delta \mathrm{H}^{*}\right)$ and entropy $\left(\Delta \mathrm{S}^{*}\right)$ were obtained from the slopes and intercept of InKd vs. $1 / T$ plots as shown in Fig. 12 .Changes in Gibbs free energy ( cimanydomreht ehT .(8) ).qE gnisu detaluclac saw ( ${ }^{*} \mathrm{G} \Delta$ 4 elbaT ni nevig era OPP yb snoi latem fo noitprosda rof sretemarap

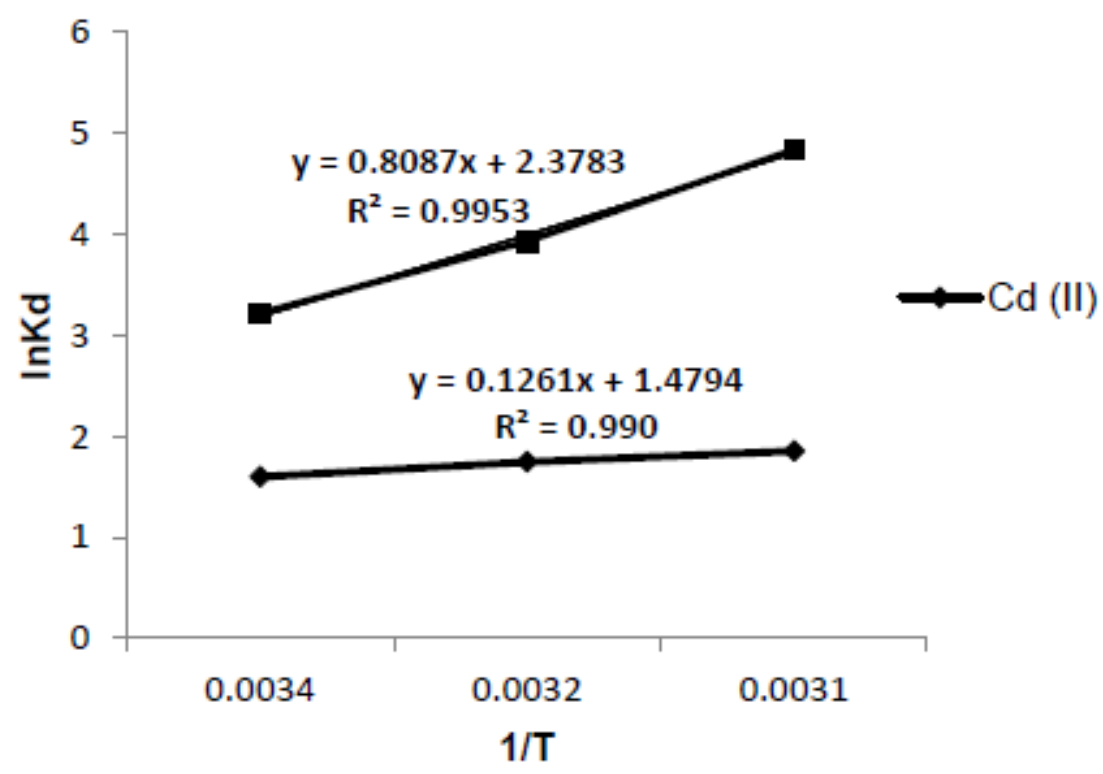

Figure 12. Plots of In $\mathrm{K}_{d}$ Vs $1 / \mathrm{T}$ for $\mathrm{Cd}(\mathrm{II})$, and $\mathrm{Hg}$ (II) metal ions at different temperatures. 
Table 4. Thermodynamic parameters for adsorption of metals ion on PPO at $298 \mathrm{~K}$.

\begin{tabular}{|c|c|c|c|}
\hline Metal ion & $\Delta \mathrm{H}^{*}(\mathrm{~J} / \mathrm{mol})$ & $\Delta \mathrm{S}^{*}(\mathrm{~J} / \mathrm{mol} . \mathrm{K})$ & $\Delta \mathrm{G}^{*}(\mathrm{KJ} / \mathrm{mol})$ \\
\cline { 1 - 1 } $\mathrm{Cd}(\mathrm{II})$ & 1.03 & 12.03 & -3.58 \\
\cline { 1 - 3 } $\mathrm{Hg}(\mathrm{II})$ & 6.58 & 19.34 & -5.76 \\
\hline
\end{tabular}

Table 4, shows that the adsorption of metal ions on PPO is a favorable process indicated by the negative value of $\Delta \mathrm{G}^{*}$. The positive $\Delta \mathrm{H}^{*}$ values reflect the endothermic nature of the adsorption process. Also, the positive values of $\Delta \mathrm{S}^{*}$ could be related to the increase of randomness, when the hydrated water molecules, that bounded to the polymer and the metal ions were replaced upon adsorption.

\subsubsection{Metal ion-uptake by the polymer using fixed bed column technique}

The applicability of PPO in the removing of heavy metals was investigated using fixed bed column. The solution of metal ions was passed through adsorbing column that contains PPO at flow rate of $1 \mathrm{~mL} / \mathrm{min}$. The percent uptake for $\mathrm{Pb}(\mathrm{II})$, $\mathrm{Cd}(\mathrm{II})$ and $\mathrm{Hg}(\mathrm{II})$ was $46.0 \%, 45.8 \%$ and $35.6 \%$, respectively. It can be seen that the order of metal ion uptake using column technique was similar to that of batch experiment; $\mathrm{Pb}(\mathrm{II})>\mathrm{Cd}(\mathrm{II})>\mathrm{Hg}(\mathrm{II})$. However, the values of metal ions uptake in column experiment were lower than those obtained in batch experiments. This could be related to the short contact time, which was not enough for achieving the complete saturation of metal ions on polymer surface.

\subsection{Desorption study}

To be useful in metal ion recycling processes, chelated metal ions should be easily desorbed under suitable conditions. Desorption experiments were performed using three eluting agents $1 \mathrm{~N} \mathrm{HNO}_{3}, 1 \mathrm{~N} \mathrm{H}_{2} \mathrm{SO}_{4}$ and $0.5 \mathrm{~N}$ EDTA keeping the flow rate of elution at $1 \mathrm{~mL} / \mathrm{min}$. The eluate was collected and the results are expressed as percent recovery as shown in Table 5.

Table 5. Percent recovery for metal ions using different eluting agents.

\begin{tabular}{rrcc}
\hline Eluting agent & \% Recovery Pb & \% Recovery Cd & \% Recovery Hg \\
\hline $1 \mathrm{~N} \mathrm{HNO}_{3}$ & 69.8 & 77.9 & 72.7 \\
\hline $1 \mathrm{~N} \mathrm{H}_{2} \mathrm{SO}_{4}$ & 12.4 & 46.8 & 46.3 \\
\hline $0.5 \mathrm{~N} \mathrm{EDTA}$ & 25.8 & 66.4 & 65.1 \\
\hline
\end{tabular}

Depending on the values of \% recovery in Table 5, the following trends were observed for the eluting agents: $1 \mathrm{~N} \mathrm{HNO}_{3}>$ $0.5 \mathrm{~N}$ EDTA $>1 \mathrm{~N} \mathrm{H}_{2} \mathrm{SO}_{4}$ for all metal ions.

The chelating strengths of the eluting agents toward different metal ions are not in agreement with the adsorption and stability constants reported for the complexation of the metal ions and used ligands which follow this order EDTA ${ }^{2-}>\mathrm{SO}_{4}{ }^{2-}$ $>\mathrm{NO}_{3}{ }^{-}$[33]. The results of the desorption process indicate that the elution of metal ions from the polymer is governed by the solubility factor.

\section{Chelation properties of the polymer in a real sample .3 .5}

A real sample was also employed in order to check the capability of metal uptake by the polymer for environmental application. A sample containing $30 \mathrm{ppm} \mathrm{Pb}$ )II) was brought from HOPPECKE batteries factory. The same procedure of metal uptake was performed on this sample keeping the exposed time at $24 \mathrm{~h}$. the percentage uptake was found about $95 \%$. The removal of $\mathrm{Pb}$ )II) from real wastewater sample was efficient, and it can be said that nearly complete adsorption was achieved, which confirm the applicability of PPO in waste water treatment.

\section{CONCLUSION}

In this work we present the preparation of poly(1,4-phenylene oxalate) (PPO) as the chelating polymer for the removal of heavy metals from aqueous solutions. The structure of the polymer was clearly confirmed by spectral analysis. From the SEM images and XRD analysis, the polymer was found to be very amorphous and porous in nature.

The kinetic study showed that the adsorption of heavy metals on PPO follows second order kinetics model. PPO showed an excellent adsorption capacity toward $\mathrm{Pb}(\mathrm{II})$ and $\mathrm{Cd}(\mathrm{II})$ compared to the previous prepared chelating polymer in the literatures include the aliphatic polyoxalate (Poly 2,2-dimethyl-1,3-propylene oxalate). The order of adsorption capacity of metal ions onto PPO was $\mathrm{Pb}(\mathrm{II})>\mathrm{Cd}(\mathrm{II})>\mathrm{Hg}(\mathrm{II})$, this order was explained by the stability of complexes that formed between polymer active groups and the metal ions.

Adsorption isotherms confirmed that the adsorption followed Langmuir monolayer adsorption. The thermodynamic parameters for the adsorption process were calculated. The positive values of $\Delta \mathrm{H}^{*}$ and $\Delta \mathrm{S}^{*}$ and negative value of $\Delta \mathrm{G}^{*}$ indicating that the metals adsorption process is endothermic and spontaneous. The regeneration study shows that PPO 
can be reused with high desorption percentage of metal ions. The investigation on real wastewater sample has also revealed PPO can be utilized to remove heavy metal ions, especially, lead from the aquatic environment.

All these findings indicate the applicability of PPO for the separation and recovery of heavy metal ions from wastewater.

\section{REFERENCES}

1. Kumi, M.; Quainoo, A.K; Charles, A.K. The role of maize tassels in amelioration of heavy metals from contaminated soils and its effects on vegetable. J. Environ. Ert. Sci. 2013, 3, 192-199.

2. Gupta, V. K.; Gupta, M.; Sharma, S. Process development for the removal of lead and chromium from aqueous solutions using red mud-an aluminum industry waste. Water. Res. 2001, 35, 1125-1134.

3. Kesenci, K.; Say, R.; Denizli, A. Removal of heavy metal ions from water by using poly (ethylene glycol dimethacrylate-co-acrylamide) beads. Eur. Polym. J. 2002, 38, 1443-1448.

4. Ali, A.E.; Shawky, H. A.; H.A. Abd El Rehim, H.A.; Hegazy E.A. Synthesis and characterization of PVP/AAc copolymer hydrogel and its applications in the removal of heavy metals from aqueous solution. Eur. Polym. J. 2003, $39,2337-2344$

5. Souda, P; Sreejith, L. Poly(acrylate-acrylic acid-co-maleic acid) hydrogel: A cost effective and efficient method for removal of metal ions from water. Separ. Sci. Technol. 2013, 48, 2795-2803.

6. Ge, F.; Li, M.M.; Ye, H.; Zhao B.X. Effective removal of heavy metal ions $\mathrm{Cd}^{2+}, \mathrm{Zn}^{2+}, \mathrm{Pb}^{2+}, \mathrm{Cu}^{2+}$ from aqueous solution by polymer-modified magnetic nanoparticles. J. Hazard. Mater. 2012, 211-212, 366-372.

7. Kiani, G.R.; Sheikhloie, H.; Arsalani, N. Heavy metal ion removal from aqueous solutions by functionalized polyacrylonitrile. Desalination. 2011, 269, 266-270.

8. Charef, N.; Benmaamar, Z.; Arrar, L.; Baghiani, A.; Zalloum, R.M.; Mubarak, M.S. Preparation of a new polystyrene supported-ethylenediaminediacetic acid resin and its sorption behavior toward divalent metal ions. Solvent Extr. Ion Exch. 2012, 30, 101-112.

9. Moussout, H.; Ahlafi, H.; Slimani, M.Y.S; Boukhlifi, F.; Daou, I. Bentonite/Chitosan biocomposite as an adsorbent for hexavalent chromium from aqueous solutions. J. Adv. Chem. 2014, 10, 2786-2795.

10. Dey R.K.; Patnaik T, Mohapatra, N.; Samal S. Removal of heavy metal ions using new chelating material containing N, O, and S donor sites. Separ. Sci. Technol. 2007, 42, 3593-3608.

11. McCullagh, C.; Saunders, G.C. Enhanced adsorption of Cd (II) on a hydrous Al(III) floc in the presence of a modified form of polyethylenimine. Water. Res. 2005, 39, 2799-2806.

12. Kuo, P.C; Lo, C.T.; Chen, C.Y. Crystallization and microstructure of poly(butylene oxalate). Polymer. 2013, 54, 6654-6662.

13. Kim, S.; Seong, K.; Kim, O.; Kim, S.; Seo, H.; Lee, M.; Khang G.; Lee, D. Polyoxalate nanoparticles as a biodegradable and biocompatible drug delivery vehicle. Biomacromolecules, 2010, 11, 555-560.

14. Park, H.; Kim, S.; Kim, Y.; Song, K.; Seung, D.; Khang G.; Lee, D. Antioxidant and anti-inflammatory activities of hydroxybenzyl alcohol releasing biodegradable polyoxalate nanoparticles. Biomacromolecules, 2010, 11, 2103-2108.

15. Al-Hamidi, S.T.; Sweileh B.A.; Khalili, F.I. Preparation and characterization of poly(bisphenol A oxalate) and studying its chelating behavior towards some metal ions. Solvent Extr. Ion Exch. 2008, 26, 145-162.

16. Garcia, J.J.; Miller, S.A. Polyoxalates from biorenewable diols via oxalate metathesis polymerization. Polym. Chem. 2014, 5, 955-961.

17. Abu-Awwad I.F.; Khalilia F.I.; Sweileh B.A. Preparation and characterization of poly(2,2-dimethyl-1,3-propylene oxalate) polymer and the study of its metal uptake behavior toward $\mathrm{Pb}(\mathrm{II}), \mathrm{Cd}(\mathrm{II})$, and $\mathrm{Hg}$ (II) lons. Solvent Extr. Ion Exch. 2010, 28, 682-705.

18. Sweileh B.A.; Al-Hiari, Y. Synthesis and thermal properties of polycarbonates based on bisphenol A by single-phase organic solvent polymerization. J. Polym. Res. 2006, 13, 181-191.

19. Cay, S.; Uyanik, A.; Ozasil, A. Single and binary component adsorption of copper and cadmium from aqueous solutions using tea-industry waste. Sep. Purif. Technol. 2004, 38, 273-280.

20. Valenzuela, F.; Valdés, A.; Ide, V.; Basualto, C.; Sapag, J.; Araneda, C. Equilibrium, kinetic, and thermodynamic analysis of $\mathrm{Cd}(\mathrm{II})$ sorption from aqueous solutions using polymeric microcapsules containing an acidic organophosphonic extractant. Solvent Extr. Ion Exch. 2012, 30, 422-430.

21. Thibeault, B.; Stickles, E.; Weininger, S. Unsaturated polyoxalates: synthesis and mass spectral study of their thermal behavior. J. Polym. Sci. A Polym. Chem. 1990, 28, 1361-1376.

22. Ohto, K.; Inoue, S.; Eguchi, N.; Shinohara, T.; Inoue, K. Adsorption behavior of lead ion on Calix[4]arene tetracarboxylic acid impregnated resin. Separ. Sci. Technol. 2002, 37, 1943-1958.

23. Chiou, M.S.; Li, H.Y. Adsorption behavior of reactive dye in aqueous solution of chemical cross-linked chitosan beads. Chemosphere. 2003, 50, 1095-1102.

24. Guibal, E. Interactions of metal ions with chitosan-based sorbents: a review. Sep. Purif. Technol. 2004, 38, 43-74.

25. Monier M.; Abdel-Latif, D.A. Preparation of cross-linked magnetic chitosan-phenylthiourea resin for adsorption of $\mathrm{Hg}(\mathrm{II}), \mathrm{Cd}(\mathrm{II})$ and $\mathrm{Zn}(\mathrm{II})$ ions from aqueous solutions. J. Hazard. Mater. 2012, 209-210, 240-249.

26. Ji, C.; Qu, R.; Wang, C.; Chen, H.; Sun, C.; Xu, Q.; Sun, Y.; Wei, C. A chelating resin with bis[2-(2benzothiazolylthioethyl)sulfoxide]: synthesis, characterization and properties for the removal of trace heavy metal ion in water samples. Talanta. 2007, 73, 195-201.

27. Bai, L.; Hu, H.; Fu, W.; Wan, J.; Cheng, X.; Zhuge, L.; Xiong, L.; Chen, Q. Synthesis of a novel silica-supported dithiocarbamate adsorbent and its properties for the removal of heavy metal ions, J. Hazard. Mater. 2011, 195, 261275. 
28. Cheng, L.; Shu-Ling, G.; Ling-Zhi, M.; Ling, H.; Huang, H.; Yong-Bing, H. Polysiloxane resins modified by bisglycidyl calix[4]arene: preparation, characterization, and adsorption behaviour toward metal ions. J. App. Polym. Sci. 2005, 95, 1310-1318.

29. Rongjun, Q.; Chunhua, W.; Chunnuan, J.; Changmei, S.; Xiangrong, S.; Guoxiang, C. Preparation characterization and metal binding behavior of novel chelating resins containing sulfur and polyamine. J. App. Polym. Sci. 2005, 95, 1558-1565.

30. Reddy, A.; Reddy, K. Heavy metal ion uptake properties of polystyrene-supported chelating polymer resins. Proc. Indian Acad. Sci. (Chem. Sci.). 2003, 115, 155-160.

31. McClain, A.; Hsieh, Y. Synthesis of polystyrene-supported dithiocarbamates and their complexation with metal ions. J. App. Polym. Sci. 2004, 92, 218-225.

32. Ravikumar, L.; Kalaivani, S.; Vidhyadevi, T.; Murugasen, A.; Kirupha, S.D.; Sivanesan, S. Synthesis, characterization and metal ion adsorption studies on novel aromatic poly(azomethine amide)s containing thiourea groups. Open J. Polym. Chem. 2014, 4, 1-11.

33. Hogefeldt, E. Stability constant of metal ion complexes, part A: Inorganic ligands; IUPAC chemical data series; Pergamon, Oxford: England, 1982, 21.

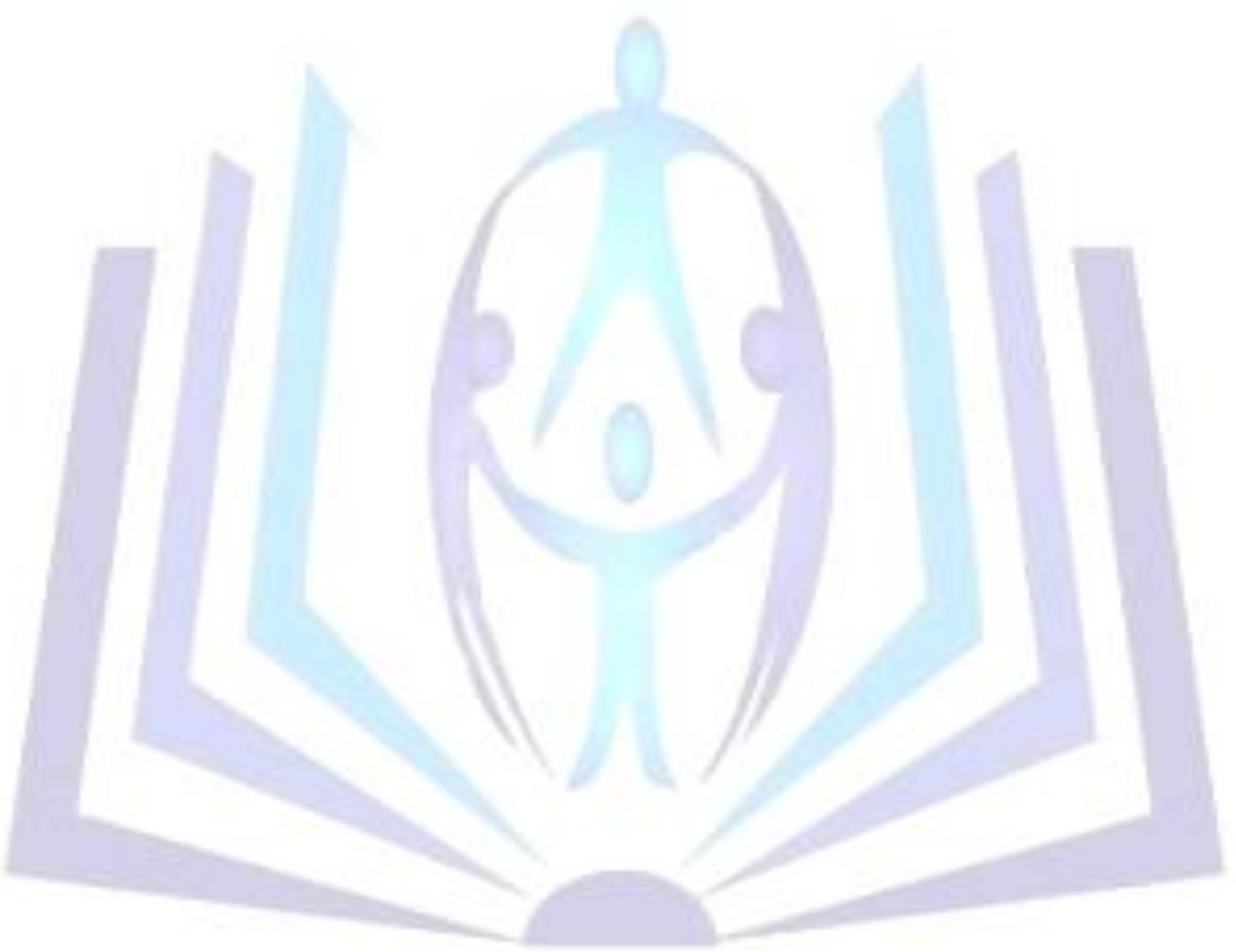

